\title{
Genetically Engineered Mesenchymal Stem Cells as a Proposed Therapeutic for Huntington's Disease
}

\author{
Scott D. Olson • Kari Pollock • Amal Kambal • Whitney Cary • Gaela-Marie Mitchell • \\ Jeremy Tempkin • Heather Stewart • Jeannine McGee • Gerhard Bauer • \\ Hyun Sook Kim • Teresa Tempkin • Vicki Wheelock • Geralyn Annett • Gary Dunbar • \\ Jan A. Nolta
}

Received: 21 August 2011 / Accepted: 9 November 2011 / Published online: 9 December 2011

(C) The Author(s) 2011. This article is published with open access at Springerlink.com

\begin{abstract}
There is much interest in the use of mesenchymal stem cells/marrow stromal cells (MSC) to treat neurodegenerative disorders, in particular those that are fatal and difficult to treat, such as Huntington's disease. MSC present a promising tool for cell therapy and are currently being tested in FDA-approved phase I-III clinical trials for many disorders. In preclinical studies of neurodegenerative disorders, MSC have demonstrated efficacy, when used as delivery vehicles for neural growth factors. A number of investigators have examined the potential benefits of innate MSC-secreted trophic support and augmented growth factors to support injured neurons. These include overexpression of brain-derived neurotrophic factor and glialderived neurotrophic factor, using genetically engineered MSC as a vehicle to deliver the cytokines directly into the microenvironment. Proposed regenerative approaches to
\end{abstract}

S. D. Olson $\cdot$ K. Pollock $\cdot$ A. Kambal $\cdot$ W. Cary $\cdot$ G.-M. Mitchell $\cdot$

J. Tempkin $\cdot$ H. Stewart $\cdot$ J. McGee $\cdot$ G. Bauer $\cdot$ H. S. Kim $\cdot$

G. Annett $\cdot$ J. A. Nolta $(\square)$

Stem Cell Program and Institute for Regenerative Cures,

University of California Davis Health Systems,

2921 Stockton Blvd., Room 1300,

Sacramento, CA 95817, USA

e-mail: Jan.nolta@ucdmc.ucdavis.edu

URL: http://www.ucdmc.ucdavis.edu/stemcellresearch

T. Tempkin $\cdot$ V. Wheelock

Department of Neurology,

University of California Davis Health Systems,

Sacramento, CA, USA

\section{H. S. Kim}

Department of Neurology, CHA University School of Medicine, Bundang, South Korea

G. Dunbar

Department of Psychology, Central Michigan University,

Mount Pleasant, MI, USA neurological diseases using MSC include cell therapies in which cells are delivered via intracerebral or intrathecal injection. Upon transplantation, MSC in the brain promote endogenous neuronal growth, encourage synaptic connection from damaged neurons, decrease apoptosis, reduce levels of free radicals, and regulate inflammation. These abilities are primarily modulated through paracrine actions. Clinical trials for MSC injection into the central nervous system to treat amyotrophic lateral sclerosis, traumatic brain injury, and stroke are currently ongoing. The current data in support of applying MSC-based cellular therapies to the treatment of Huntington's disease is discussed.

Keywords Human mesenchymal stem cells .

Neurite outgrowth - Neurodegenerative diseases .

Hypoxia - Tissue repair · Huntington's disease ·

Clinical trials $\cdot$ BDNF

$\begin{array}{ll}\text { Abbreviations } \\ \text { ALS } & \text { Amyotrophic lateral sclerosis } \\ \text { BDNF } & \text { Brain-derived neurotrophic factor } \\ \text { CSF } & \text { Cerebrospinal fluid } \\ \text { FGF-2 } & \text { Fibroblast growth factor-2 } \\ \text { GDNF } & \text { Glial-derived neurotrophic factor } \\ \text { GMP } & \text { Good Manufacturing Practice } \\ \text { GLP } & \text { Good laboratory practice } \\ \text { HD } & \text { Huntington's disease } \\ \text { HGF } & \text { Hepatocyte growth factor } \\ \text { hESC } & \text { Human embryonic stem cells } \\ \text { HSCT } & \text { Hematopoietic stem cell transplantation } \\ \text { HTT } & \text { Huntingtin gene, mRNA, or protein } \\ \text { IGF-1 } & \text { Insulin-like growth factor-I } \\ \text { MSC } & \text { Mesenchymal stem cells } \\ \text { NSC } & \text { Neural stem cells } \\ \text { OEC } & \text { Olfactory ensheathing cells }\end{array}$


siRNA Small interfering ribonucleic acid

SOP Standard operating procedure

SVZ Subventricular zone

TBI Traumatic brain Injury

QA Quinolinic acid

QA/QC Quality assurance/quality control

VEGF Vascular endothelial growth factor

\section{Introduction}

Human mesenchymal stem cells are known to secrete a variety of cytokines and growth factors that have both paracrine and autocrine activities for damaged tissues, including the brain (reviewed in [1]). The mechanism of action of adult MSC obtained from bone marrow or adipose tissue is based on the innate functions of these stem cells: the injected cells home to the injured area, in particular to hypoxic, apoptotic, or inflamed areas, and release trophic factors that hasten endogenous repair. These secreted bioactive products can suppress local inflammation, enhance angiogenesis, reduce levels of free radicals, inhibit fibrosis and apoptosis, and stimulate recruitment, retention, proliferation, and differentiation of tissue-residing stem cells (reviewed in [2]). These paracrine effects are distinct from the classical model of direct differentiation of stem cells into the tissue to be regenerated.

MSC are ideally suited for cellular therapy due to their ease of isolation, manipulation, and safety. They can be expanded from normal qualified human donors in large quantities and can be infused without tissue matching, since they shield themselves from the immune system [3]. The ability to be transplanted without tissue matching has allowed large multicenter trials to be conducted with direct comparison of the same batches of MSC across hundreds of patients, without adverse events or rejection reactions [4, 5]. Due to the promise of MSC in cellular therapies, a variety of studies have focused initially not only on their characterization but also on their utility in treatment of several diseases in animal models. MSC contributed significantly to the recovery of tissues in models of myocardial infarction [6], stroke [7, 8], meniscus injury [9], and limb ischemia [10]. However, the number of engrafted MSC was consistently low in the damaged tissue, suggesting that their efficacy relies upon actions other than direct differentiation. Kinnaird et al. [11] demonstrated that MSC-conditioned media stimulated endothelial cell proliferation and migration in vitro, and the injection of MSCconditioned media into mice that had undergone hind limb ischemia was sufficient to mediate regeneration of the blood flow in the injured limb. Similar results have been shown with a cardiac infarction model [12], and the secretion of multiple angiogenic cytokines from MSC has been demonstrated.
Hepatocyte growth factor (HGF), fibroblast growth factor-2 (FGF-2), insulin-like growth factor-1 (IGF-1), and vascular endothelial growth factor (VEGF) have all been detected in MSC-conditioned medium. The increasing body of evidence points toward the theory that a complex set of trophic factors secreted by MSC significantly contributes to injury repair in vivo, through stimulating angiogenesis, reducing oxidative stress, and decreasing apoptosis.

MSC have been found to produce improvements in disease models even though a limited number of the cells could be demonstrated to be stably engrafted. A mystery that remains in the MSC field is that, while MSC persist long-term in the tissues of non-injured or chronically damaged mice, in cases of acute injury or inflammation, MSC respond to the injury robustly, but only transiently and do not become an enduring part of the repaired tissue or vasculature to any significant degree. We have studied this disparity in immune deficient mice that cannot reject the human cells, so the disappearance of MSC is independent of an immune rejection. One month post-infusion MSC are often virtually undetectable at the area of acute tissue damage [13-15]. The same phenomenon has been observed in large animal models. In contrast, when labeled MSC, cultured in the same way, are infused intravenously into immune deficient mice that have lowlevel systemic damage from irradiation, a chronic disease, or no damage at all, the cells migrate through all tissues and persist in a relatively evenly dispersed and longlasting manner $[16,17]$. We have recovered human MSC from numerous organs of the mice at time points from 1 to 18 months post-transplantation in those cases [16-20], whereas in the acute injury setting, they are only transiently recovered.

In our previous studies, hypoxic preconditioning was found to enhance MSC efficacy in a severely hypoxic tissue ischemia model, perhaps by priming MSC to respond to the low oxygen environment [14]. We are currently using the hypoxic preconditioning method to prepare MSC for injection into the striatum in murine models of HD. Further studies must be done to better understand the duration of the residence of infused MSC in tissues, including the brain, and the mechanisms that recruit and retain them in chronic vs. acute tissue damage environments. This knowledge will allow the most effective use of MSCbased cellular therapies.

\section{MSC in Neural Repair-Overview}

There is currently much interest in the use of MSC to treat neurodegenerative diseases. In particular degenerative diseases like Huntington's disease that are fatal and difficult to treat, MSC may prove therapeutic by providing neuro- 
trophic factors to encourage repair and potentially new growth of neurons from endogenous neural progenitor cells. Proposed regenerative approaches include delivery via intracerebral or intrathecal injection or even infusion via an intranasal route [21]. Therapies will capitalize upon the innate trophic support from MSC or on additional augmented growth factor support. Genetically engineered MSC can serve as the vehicle to deliver brain-derived neurotrophic factor (BDNF) or glial-derived neurotrophic factor (GDNF) into the brain to support injured neurons, as reviewed in this report.

Upon transplantation, MSC in the brain promote endogenous neuronal growth, decrease apoptosis, and regulate inflammation through the use of secreted factors. Rossignol et al. [22] demonstrated that after xenotransplantation of human MSC into rat brain, there were higher levels of messenger RNAs (mRNAs) for the anti-inflammatory molecules IL- 6 and TGF- $\beta_{1}$ than for the pro-inflammatory cytokines IL-8 and IL-12. MSC can mediate modification of the damaged tissue microenvironment to enhance endogenous neural regeneration and protection. MSC transplanted at sites of nerve injury have been shown to promote functional recovery by producing trophic factors that induce survival and regeneration of host neurons [23]. Transplantation of human bone marrow stem cells into the brains of immunodeficient mice markedly increased the proliferation of endogenous neural stem cells [24]. In an experimental allergic encephalomyelitis model of multiple sclerosis, rodents that received an intraventricular infusion of MSC were found to have almost twice the number of axons as control animals [25]. Busch et al. [26] demonstrated that human multipotent adult progenitor cells, a precursor of MSC, prevented axonal dieback and significantly enhanced neurite growth into the lesion core after a spinal cord injury. Although candidate molecules are under investigation, further detailed studies are needed to carefully define the factors responsible for the MSC-mediated induction of proliferation and enhancement of axonal extension and synaptic connection in resident neural stem cells, in order to best capitalize upon this type of therapy for the repair of neurodegenerative diseases.

Several groups have shown that intraparenchymal delivery of human MSC is safe and can delay loss of motor neurons in rodents. Vercelli et al. [27] transplanted human MSC directly into the lumbar spinal cords of SOD1 ALS mice. The MSC migrated throughout the spinal cord and delayed loss of motor neurons, prolonging motor performance. Another study compared the efficacy of transplanting olfactory ensheathing cells (OEC) and rat MSC intrathecally through the fourth ventricle in the spinal cord. The OEC distributed widely, but significant changes in clinical outcomes were observed only with addition of MSC transplantation when female ALS mice showed statistically longer lifespans than males and control mice [28].

Numerous clinical trials have demonstrated the low risk of systemic infusion of allogeneic MSC into patients with various diseases. Biosafety monitoring of MSC infusion has been performed throughout these trials, with no serious adverse events reported. For direct infusion of MSC into the brain or spinal cord, the biosafety aspects should be monitored extremely carefully. Possible risks include the development of cytogenetic abnormalities in cultured cells or ectopic differentiation to other tissue lineages. The development of cytogenetic abnormalities when MSC were cultured past the crisis point has been reported in rodent MSC [29]. In our lab, we have found that, in general, rodent MSC cultures are frequently contaminated with hematopoietic elements and do not well reflect human MSC biology. There has been only one report of a karyotypic abnormality happening in human MSC that were cultured in conditions that would never be allowed in a good manufacturing practice (GMP) or good laboratory practice (GLP) setting [30]. It was later found that the tumor arose due to cross-contamination of MSC cultures with fibrosarcoma and glioma cells [31]. When human MSC are cultured under GLP/GMP conditions, with appropriate release criteria, adverse events have not been observed throughout the field, both in vivo and in numerous human clinical trials [1, 2, 32-38]. We have published a decadelong biosafety study on the clinical biosafety profile of genetically engineered MSC [18].

A potential risk for infusion of MSC into the spinal cord or brain is that they have potent revascularization capacity and will home to the hypoxic region around a tumor bed $[39,40]$. This tropism for the tumor or wound bed could result in enhanced revascularization and survival of a growing tumor. Therefore, in proposed cellular therapy trials, an important exclusion criterion is the lack of prior brain tumors or other cancers in the past 5 years. Magnetic resonance imaging (MRI) or other functional imaging modalities should be done prior to treatment in HD trials to establish the baseline striatal volume [41, 42] and would be also used to rule out existing brain tumors.

Several groups have reported that MSC can be induced to express neural markers in vitro, in particular after cocultivation with human or murine neurons or conditioned medium. However, although mature neurons with functional activity can be generated in culture from neural stem cells (NSC) [43, 44], it has not been shown conclusively that mature neurons with signaling capacity can be generated from MSC [45]. While attractive in theory, MSC do not appear to be a viable alternative to NSC as a neural tissue replacement strategy. It has been reported that undifferentiated MSC often express a number of proteins used as markers of neural differentiation [46]. 
Additionally, MSC can assimilate proteins and pieces of membrane from other cells, requiring more definitive proof of "trans-differentiation" of MSC to neurons, particularly in co-cultures and in vivo where MSC have extensive contact with neural tissue. Recent studies have shown that RNA species and proteins can be passed from mammalian donor cell to target cell, through gap junctions, exosomes, virtosomes, or tunneling nanotubules [47-49]. RNA interference (RNAi) molecules were found to be secreted in microvesicles, which later fused with other cell [50-53]. Ratajczak et al. [54] described horizontal transfer of mRNA from cell to cell through embryonic stem cell-derived microvesicles. Virtosomes were recently described to be complexes of RNAlipoprotein, which can readily enter other cells where they can modify the biology of the recipient cells [47]. Tunneling nanotubes have also been described for transferring RNA species and organelles between cells [48]. Our group is currently exploring an MSC-based platform for producing and delivering RNAi moieties targeted to the huntingtin mRNA as a potential therapeutic avenue for treating HD [55]. We chose to explore human MSC, which we and others have previously shown to be excellent in vivo delivery vehicles for enzymes and proteins, as the cell type to produce and convey RNAi [2, 17]. Transfer of organelles as large as mitochondria from MSC to damaged cells has also been described [56]. Therefore, reports of MSC trans-differentiating to neural phenotypes, particularly after co-cultivation with neurons, must be cautiously interpreted. However, the ability of MSC to migrate to areas of damage in the brain and to secrete neurorestorative factors is significant and could be harnessed to treat neurodegenerative disease.

\section{Expression of Neuroregulatory Factors by MSC}

Understanding the innate capacity of MSC to influence neural cell growth, survival, and neurite extension is currently a very important field of study. Detailed determination of which factors MSC express, under which conditions, is key. Crigler et al. [23] demonstrated that specific subpopulations of human MSC expressed BDNF and beta-NGF, but not neurotrophins NT-3 or NT-4. The authors used a co-culture assay to show that BDNF expression levels correlated with the ability of MSC subclones to induce survival and neurite outgrowth in the SH-SY5Y neuroblastoma cell line. The effects were only partially inhibited by a neutralizing anti-BDNF antibody, indicating that other factors secreted by the MSC also had neuroregulatory effects. The authors identified production of other neurite-inducing factors, axon guidance, and neural cell adhesion molecules, which contributed to the capacity of the MSC to induce neuronal cell survival and nerve regeneration. Wilkins et al. [57] have also demonstrated that MSC secrete BDNF and that addition of anti-BDNF neutralizing antibodies attenuated their neuroprotective effects. These studies help to at least partially determine the mechanisms of MSC-mediated neural survival and also validate the important role of BDNF in neuronal protection.

In addition to neurotrophic factors, the extracellular matrix (ECM) molecules produced by MSC have also been shown to support neural cell attachment, growth, and axonal extension [58]. Neurons on ECM derived from MSC formed more complex neurite networks than those cultured on poly-D-lysine [58]. Croft et al. [59] showed that soluble factors produced by MSC promoted the survival of neurons in culture and promoted axonal growth in neuronal progeny. The authors proposed mechanisms to manipulate MSC in vitro prior to transplantation that could potentially further enhance the endogenous neurogenic response to injury. Different extracellular matrix scaffolds have also been examined to enhance survival of stem cells after implantation to damaged areas of the brain, and some ECM molecules can synergize with the neurorestorative effects of MSC [60]. However, a highly important consideration is to not use matrix proteins such as fibronectin that could enhance fibroblastic differentiation from MSC, which could risk scarring and microglial activation. Therefore, such scaffolds for implantation must be carefully tested in animal models of HD before consideration for future clinical application.

MSC provide a very promising platform from which to produce factors for neural regulation. Viral vectors under inducible promoters can be used to customize MSC for the treatment of specific diseases, as described in more detail below. Overexpression of BDNF is a particularly promising modification for HD. A traditional gene therapy approach, where the neurons would be directly infected in vivo by live lentiviral or AAV vectors carrying BDNF would suffer from a number of safety concerns. Integrating virus can pool at the injection site, superinfecting neighboring cells and limiting distribution beyond a small area. Viral integrations can be controlled ex vivo with MSC and limited to one to two viral integrants per MSC genome, as suggested by the FDA for stem cell gene therapy trials. Using MSC as the delivery vehicle, a "suicide gene" such as thymidine kinase can also be used to eliminate a graft if anything went wrong. This would not be possible with vector-mediated delivery since the "suicide approach" would destroy the neuron into which the gene had integrated. The natural reparative characteristics of MSC can act synergistically with the growth factors that they produce. MSC could potentially migrate to injured cells to deliver BDNF locally. 
For any planned delivery method, it will be important to provide a precise and quantitative evaluation of BDNF protein level in the human CNS, perhaps by conducting a spinal tap after the therapy. Methods for precise quantitation of BDNF have been described by Zuccato et al. [61, 62]. BDNF is a complex protein that could have unwanted side effects if expressed at very high levels. It will also be important to regulate BDNF levels using an inducible promoter system, since transgenic mouse models have shown that high levels of BDNF overexpression in the brain can interfere with normal brain function by causing learning impairments and increased excitability [63].

Discussion of potential therapeutic approaches in the context of MSC-based treatments and growth factor delivery for HD is presented in this review.

\section{Huntington's Disease}

$\mathrm{HD}$ is an incurable inherited genetic disorder where the condition of the patients inexorably worsens and their prognosis is eventual death, following decline in control of emotion, movement, and cognition. The pathology of HD is caused by a variable sized polyglutamine expansion of the protein product of the huntingtin (HTT) gene. Multiple disease mechanisms have been described for HD neurodegeneration and are currently under investigation in the search for therapeutics. HD is a challenging disease to treat. Not only do the affected, dying neurons need to be rescued or replaced, but the levels of the toxic mutant protein must also be diminished to prevent further neural damage and to halt progression of the movement disorders and physical and mental decline associated with HD.

The best hope for halting HD progression is to reduce or eliminate the mutant Htt protein in the affected cells [64, 65]. Small interfering RNAs (siRNA) have been shown to be effective at reducing Htt levels and ameliorating disease symptoms in animal models $[66,67]$. Exciting new data shows that the mutant HTT mRNA can be specifically silenced by targeting conserved single nucleotide polymorphisms in the mutant allele, while sparing the transcript produced by the normal allele [68-70]. The challenge for this technology is to deliver the siRNA into the human brain in a sustained, safe, and effective manner. Our group is currently funded by the California Institute for Regenerative Medicine to develop an siRNA delivery system using human MSC as the "production factories" in the brain. Safety and efficacy studies are ongoing [55].

Many studies have demonstrated the safety and efficacy of MSC injection into the brain and central nervous system. Lescaudron and colleagues [71] transplanted autologous bone marrow stem cells into the damaged striatum of the rat HD model and found that the transplant significantly reduced working memory deficits. The transplanted MSC remained undifferentiated, but exerted trophic effects on the injured tissue. Bantubungi et al. [72] found that the lesioned environment of the striatum favored the proliferation and intralesional distribution of MSC. Several groups have shown that striatal atrophy in models of HD is accompanied by the subsequent enlargement of lateral ventricles [73, 74]. The reduction in volume of the lateral ventricle can thus be a good indicator of repair in HD correction studies. Amin et al. [73] demonstrated that after MSC implantation into the striata of rats with a unilateral damage model of HD, striatal atrophies were significantly reduced. Consequently, the volume of the lateral ventricle returned to a significantly smaller size, approaching the normal contralateral ventricle. Their results demonstrated the potential for MSC in the treatment of microanatomical defects in the motor disorders of HD.

Groups who have evaluated the impact of intrastriatal transplantation of MSC in rodent models of HD are summarized in Table 1 [73, 75-82]. Some groups had hoped to observe MSC becoming neurons after transplantation. However, as discussed above, although some neuronal markers can be observed on transplanted MSCs due to their propensity for "sharing" membrane and cytoplasmic markers and natural expression of a number of traditionally neural markers like nestin [46], bona fide transdifferentiation into functional neurons has not been convincingly demonstrated. In contrast to "transdifferentiation" to neural cells, through the ability of MSC to secrete neurotrophic factors, reduce inflammation, reduce apoptosis, enhance axonal extension, and reduce reactive oxygen species, significant positive effects were seen in alleviating HD progression in the studies listed.

Data suggest that MSC implantation into the striatum can potentially delay the unrelenting loss of medium spiny neurons in HD. An important factor to consider is that the MSC implanted at adjacent sites have the capacity to migrate into the most damaged areas in response to stress or death of medium spiny neurons, which are lost in HD. MSC are known to migrate robustly in the brain, in response to injury. Delcroix et al. [83] demonstrated that iron nanoparticle-labeled MSC migrated from an implantation site in the subventricular zone microenvironment toward the olfactory bulb through the rostral migratory stream only when a mechanical lesion of the olfactory bulb was performed. They confirmed the known potential of MSC to migrate toward areas of damage, even over a great distance in the brain. The migratory capacity of MSC was further examined by transplantation of the cells a distance from a quinolinic acid (QA)-induced striatal lesion, a rat model for Huntington's disease [82, 84]. Migration was monitored using MRI scans followed by histology. The engrafted MSC were shown to have migrated a great 
Table 1 Mesenchymal stem-cell-based treatment of HD in preclinical rodent models

\begin{tabular}{|c|c|c|c|c|c|}
\hline References & Animal model & Transplanted cells & Histology & Lesion volume & Functional outcome \\
\hline Amin et al., [73] & Rat, QA & Rat BM-MSCs & Reduced striatal atrophy & Improved striatal volume & ND \\
\hline $\begin{array}{l}\text { Lee et al., } \\
\text { [79] }\end{array}$ & Rat, QA & Human adipose MSCs & $\begin{array}{l}\text { Reduced striatal atrophy } \\
\text { Reduced apoptosis }\end{array}$ & Decreased lesion volume & $\begin{array}{l}\text { Reduced Apo-M induced } \\
\text { rotations }\end{array}$ \\
\hline $\begin{array}{l}\text { Lin et al., } \\
{[80]}\end{array}$ & Mice, QA & Human BM-MSCs & $\begin{array}{l}\text { Increased cell proliferation } \\
\text { in striatum }\end{array}$ & Decreased lesion volume & $\begin{array}{l}\text { Improved rotarod performance } \\
\text { Extended survival time }\end{array}$ \\
\hline Lin et al., [80] & R6/2-J2 mice & Human BM-MSCs & Improved cell differentiation & ND & Improved survival \\
\hline Jiang et al, [78] & Rat, QA & Human BM-MSCs & Reduced striatal atrophy & Decreased lesion volume & Reduced motor dysfunction \\
\hline Lee et al., [79] & R6/2 mouse & Human adipose MSCs & $\begin{array}{l}\text { Reduced HTT aggregates } \\
\text { Attenuated loss of striatal neuron }\end{array}$ & Improved striatal volume & $\begin{array}{l}\text { Improved rotarod } \\
\text { Reduced clasping } \\
\text { Improved survival }\end{array}$ \\
\hline $\begin{array}{l}\text { Rossignol et al., } \\
\text { [81] }\end{array}$ & Rat, 3NP & Rat BM-MSCs & ND & $\begin{array}{l}\text { Prevented 3NP-mediated } \\
\text { ventricle enlargement }\end{array}$ & $\begin{array}{l}\text { Improved rotarod } \\
\text { Improved paw placement }\end{array}$ \\
\hline $\begin{array}{l}\text { Sadan et al., } \\
\text { [82] }\end{array}$ & Rat, QA & Rat BM-MSCs & $\begin{array}{l}\text { Improved MSC migration } \\
\text { to lesion }\end{array}$ & Decreased lesion volume & $\begin{array}{l}\text { Regenerated striatal network } \\
\text { Reduced Apo-M induced } \\
\text { rotations }\end{array}$ \\
\hline Im et al., [77] & YAC 128 mice & Human adipose MSCs & Reduced striatal atrophy & Improved striatal volume & $\begin{array}{l}\text { Improved rotarod } \\
\text { performance/motor function }\end{array}$ \\
\hline $\begin{array}{l}\text { Edalatmanesh et al., } \\
{[76]}\end{array}$ & Rat, QA & Rat BM-MSCs & ND & ND & $\begin{array}{l}\text { Reduced Apo-M induced } \\
\text { rotations } \\
\text { Improved beam walk } \\
\text { Improved hang wire time }\end{array}$ \\
\hline Dey et al., [93] & YAC 128 mice & $\begin{array}{l}\text { BM-MSCs engineered } \\
\text { to produce BDNF }\end{array}$ & Reduced striatal atrophy & Improved striatal volume & $\begin{array}{l}\text { Improved rotarod performance } \\
\text { Reduced hindlimb clasping }\end{array}$ \\
\hline
\end{tabular}

distance along the internal capsule toward the QA-induced lesion in the striatum. They were shown to have regenerated the damaged striatal dopaminergic nerve terminal network in this animal model for HD [82, 84].

A human cellular therapy trial has already demonstrated progress in the treatment of HD by intracerebral implantation. Bachoud-Levi and colleagues $[85,86]$ transplanted human fetal neurons into the brains of five patients with HD. Three out of five patients with HD produced motor and cognitive improvements 2 years after the fetal neural graft. The authors obtained convincing evidence that these human fetal striatal grafts were capable of reconnection and activation of the frontal lobes. Clinical improvement plateaued after 2 years and then faded off variably 46 years after the implantation $[85,86]$. These and other studies demonstrate that fetal striatal neurons can be safely implanted into the brain without adverse events. The group is currently conducting phase II clinical trials.

Since fetal striatal tissue could be a limiting factor, an alternative might be derivation of striatal neurons from human embryonic stem cells. However, a major challenge yet to be robustly achieved from embryonic stem cellderived neurons is to coerce the new neurons make bona fide synaptic connections, as the Bachoud-Levi group had seen from the fetal neurons. Co-transplantation of fetal or embryonic stem cell-derived neural grafts with MSC to enhance neuritogenesis and to guide axonal pathfinding through areas of damage could be considered [26].

A confounding factor for the treatment of HD by cellular therapy is the continued presence of the mutant HTT mRNA and protein in neighboring cells causing chronic damage, even if new, healthy neurons are implanted. Efforts to specifically knock down the expression of this mutant HTT mRNA and protein prior to or simultaneously with the MSC-based therapies must be considered [68-70].

\section{Neural Growth Factor Delivery by MSC}

An interesting development candidate that we and others are characterizing is allogeneic human MSC engineered to secrete BDNF (Fig. 1). This candidate therapy could provide a potential strategy to enhance striatal neuron survival and regeneration in HD. BDNF levels are very low in mice and humans with HD. In rodent models, BDNF has been shown to ameliorate symptoms and to extend survival, making BDNF therapy a leading candidate for use in treating HD. Striatal neurons depend on BDNF for function and survival $[87,88]$. In the later stages of $\mathrm{HD}$, available BDNF levels plummet since the mutant protein prevents production at the mRNA level [61]. This reduction in BDNF affects the onset and severity of the disease in HD 


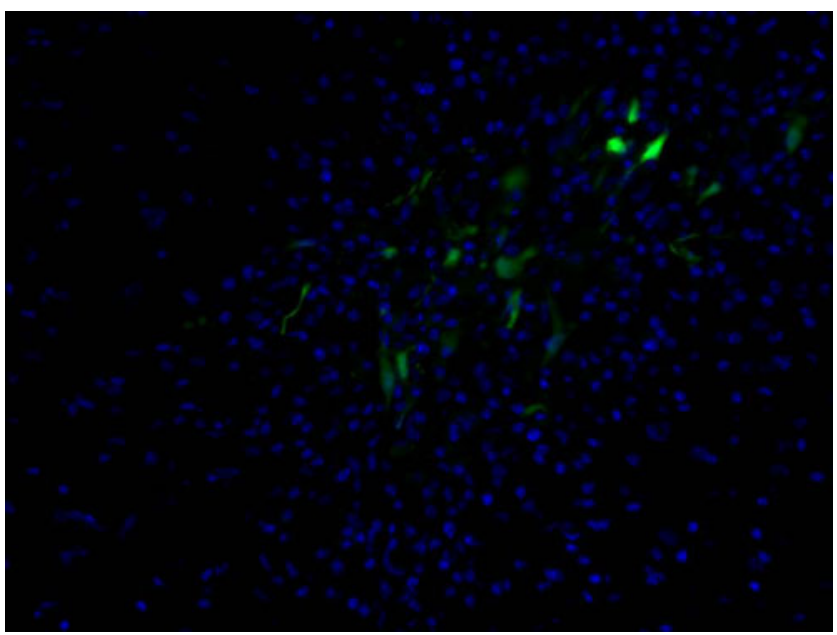

Fig. $1 \mathrm{MSC} / \mathrm{BDNF}$ in the brain of an immune deficient mouse. Human mesenchymal stem cells engineered to secrete brain-derived neurotrophic factor (BDNF) and a reporter gene (enhanced green fluorescent protein, or eGFP) were transplanted into the brain of immune-deficient mice using stereotactic injection. Tissues were harvested for assessment of human cell engraftment and biosafety at different timepoints. Shown is engraftment at 6 days post-injection

mice. Up-regulation of BDNF in the brains of transgenic rodent models of HD has shown amelioration of the disease phenotype [89]. Adenoviral astrocyte-specific expression of BDNF in the striata of mice transgenic for HD was shown to delay the onset of the motor phenotype [90]. Due to its pro-survival effects in striatal neuropathology, BDNF is a leading candidate for neuroprotective therapies in HD $[62,91,92]$.

In transgenic mouse models of $\mathrm{HD}$, there is a significant reduction in the aberrant behavioral phenotype following administration of MSC/BDNF [93]. The Dunbar laboratory has shown that MSC, especially those engineered to over-express BDNF, have significant ameliorative effects on disease progression in a transgenic mouse model of HD [93]. These studies have demonstrated that MSC engineered to produce BDNF and implanted into the striata significantly increased time to fall in rotorod testing, demonstrating an increase in coordination and reduction in movement disorders in treated mice during the 13 months of the study. The MSC/BDNF therapeutic also significantly reduced limb clasping, a hallmark behavioral defect in HD mice, over the same time period [93].

A major impediment for the clinical use of neurotrophic factors is their inability to cross the blood-brain barrier in therapeutic amounts. In the quest to begin translating promising studies such as those published by Dey et al. [93] to the clinic, we have shown biosafety of intracranial administration of MSC in long-term rodent and non-human primate models. Our group uses human MSC as safe and long-lived delivery factories for cytokines and growth factors $[2,17,94]$. We are currently evaluating the safety and efficacy of MSC engineered to secrete BDNF in peripheral tissues and in the brain to enhance neurorestorative capacity in HD (Fig. 1).

The use of MSC to deliver factors, both through their own innate responses and through engineering, has benefits beyond direct protein administration. Transplanted MSC can provide sustained and long-term delivery of factors at supraphysiological levels, as we and others have shown over the past two decades [17, 19, 20, 95-98]. Using immune-deficient mouse models, we have recovered human MSC from numerous organs at timepoints from 1 to 18 months post-transplantation, with continued expression of the gene product $[16,17,19,94,95,97$, 99]. We also performed a decade-long biosafety study to demonstrate that genetically engineered human MSC are safe, with no adverse events ever having been observed in vivo [18]. Efforts from our group and others are currently evaluating the effects of BDNF expression from human MSC implanted into the striata of HD mice. Taken together, the data discussed in the current review provide support for the potential for MSC to deliver augmented neurotrophic support.

\section{Clinical Trials of MSC for Neural Repair}

The ability of MSC to secrete factors to decrease motor neuron death when implanted into the CNS of ALS patients was assessed in a human clinical trial $[100,101]$. Ten patients with ALS who had severe functional impairment of their legs were enrolled in the MSC clinical trial with no adverse events. Autologous MSC were isolated from the patient's own bone marrow and expanded using good manufacturing practice conditions. Expanded MSC were suspended in autologous cerebrospinal fluid (CSF) and transplanted into the recipient's spinal cord at a high thoracic level. No immediate or delayed transplantrelated toxicities were observed. Patients were regularly monitored before and after transplantation using clinical, psychological, neuroradiological, and neurophysiological evaluations. Three months after cell implantation, a trend toward slowing of the decline in muscular strength was observed in the legs of four of the first seven patients treated. No significant acute or late side effects were evidenced, and four of the patients showed significant slowing of disease progression [101]. These studies demonstrated that MSC infusion into the cerebrospinal fluid can be tolerated without adverse events in patients with ALS [101]. A phase II clinical trial using MSC is underway in Europe, and the FDA has recently approved a phase I trial of MSC delivery to the CNS for ALS in the United States. 
A pilot trial using either intravenous- or intrathecalinjected MSC has been conducted by Karussis and colleagues in 12 patients diagnosed with untreatable neurodegenerative diseases-ALS or multiple sclerosis [102]. Their intent was to demonstrate the safety of the delivery methods and treatment with autologous MSC. They initiated the pilot trial after in vitro and pre-clinical investigations had demonstrated immunomodulatory effects of MSC with suppression of self-reactive T lymphocytes. In addition, animal studies in mice with chronic progressive experimental autoimmune encephalomyelitis had mitigation of their clinical course accompanied by histopathological evidence of neuroregeneration following IC and IV injection of MSC [103]. Their study was extended to include 10 ALS and 10 MS patients showing proof of concept that both delivery methods were feasible and safe. They are currently conducting a larger phase I/II trial delivering autologous MSC as treatment in patients with severe refractory MS [104]. Additional case reports and a small pilot study including 10 patients with multiple sclerosis treated with autologous MSC have been conducted with intriguing results (Bonab et al. [105-107]). Currently, there are at least four clinical trials being conducted at centers in UK, Israel, Spain and the USA evaluating the safety and efficacy of bone-marrow-derived MSC in treatment of MS.

Direct injection of MSC into the injured region of the brain during surgery following traumatic brain injury (TBI) has also been performed without adverse events. Seven TBI patients each received up to $10^{9}$ expanded MSC during the cranial repair operation [108]. Patients were followed for 6 months and demonstrated significant improvements in neurologic function. Placebo-controlled trials for MSC injection into the CNS for TBI and stroke, as well as spinal cord injury and neurodegenerative disorders, are currently ongoing in countries outside of the USA (clinicaltrials.gov). No adverse events have been reported from these studies. As one example, Venkataramana et al. [109] recently reported safety data from an open label phase I clinical trial where autologous bone-marrow-derived MSC were transplanted into the striata of patients with advanced PD. No adverse events occurred and possible clinical improvement was observed.

Clinical trials of an MSC-like multipotent cellular product, Multistem [110, 111], has been approved by the FDA to treat stroke in the USA, by the company Athersys. Celgene is approved for a multicenter phase II clinical trial to use placental-derived MSC for treating stroke, and San-Bio is conducting a phase I trial of gene-modified

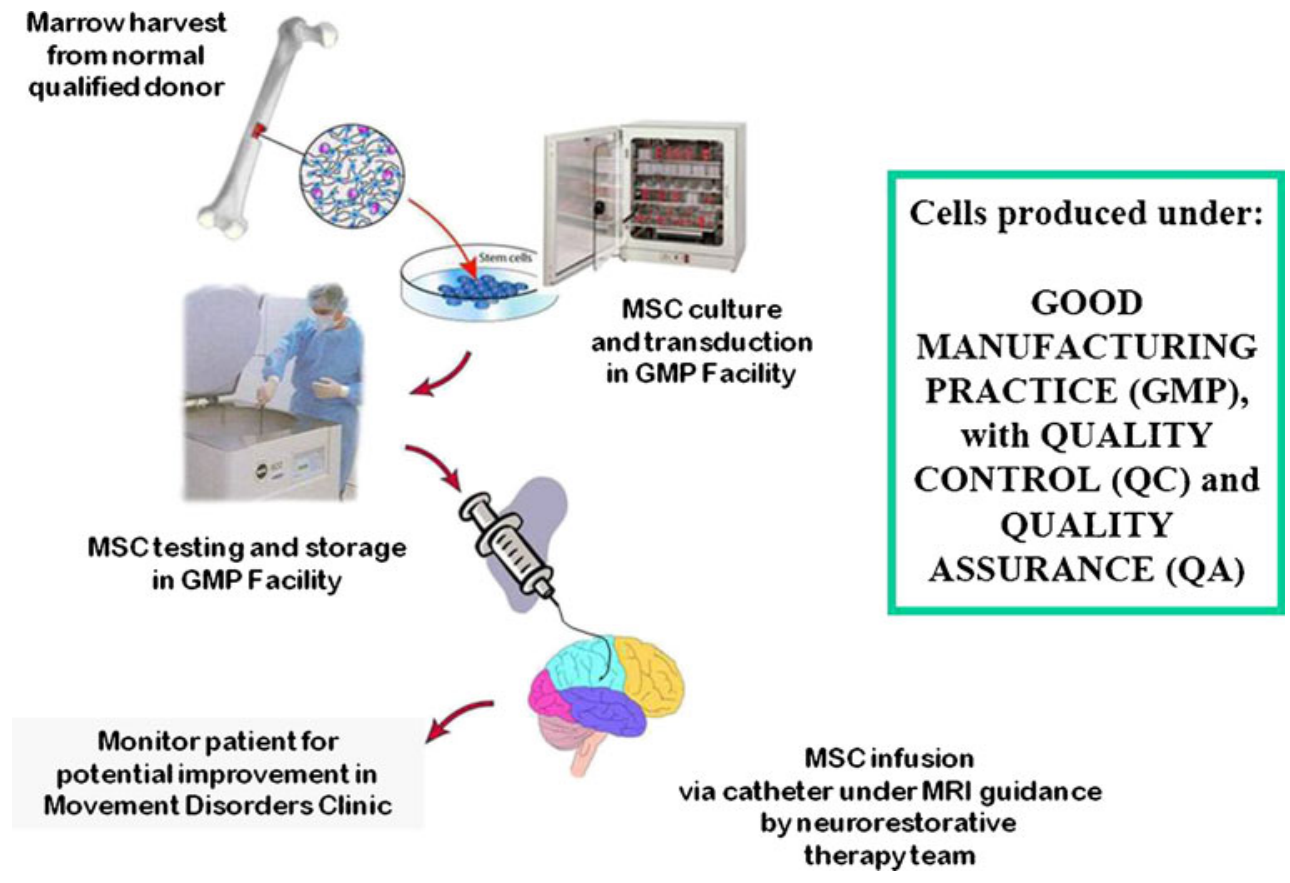

Fig. 2 Schema of proposed human MSC therapy for neurodegenerative disease. Bone marrow is harvested from a normal, qualified donor. MSC are expanded and transduced with viral vectors in the good manufacturing practice facility using qualified reagents and well-established standard operating procedures. The transduced cells are expanded, tested extensively, and banked. Following FDA clearance of the phase 1 clinical trial, the qualified cells will be implanted near the affected portion of the brain in symptomatic HD patients. MSC will be thawed, tested, and infused under MRI guidance by an experienced Neurorestorative Therapy Team. Patients will then be followed by experienced clinicians in the movement disorders clinic for evaluation of potential neurorestorative effects: slowing of disease progression as measured by total functional capacity score and delay in volumetric MRI changes known to occur in HD. Potential clinical improvement in severity of movement disorders and cognitive impairment as measured by the Unified HD Rating Scale (UHDRS) and a battery of cognitive tests will be monitored 
MSC for stroke. Osiris therapeutics has conducted multiple clinical trials using allogeneic MSC administered through systemic infusion. No stem-cell-related events have occurred and their studies provide extensive safety and provisional efficacy data for allogeneic bone-marrowderived MSC administration to patients through FDAapproved clinical trials [4, 5, 33].

Patient safety and the potential benefit to risk ratio are always the foremost considerations by the Food and Drug Administration. This review has covered the potential benefits of MSC-based therapies for the treatment of neurodegenerative diseases, and Huntington's disease in particular. We and many others have documented the biosafety of MSC therapies, which are now in phase III trials for some indications, and further safety and efficacy data are being collected by numerous groups. The need for safe and effective cellular therapies to treat HD is great. Current therapies only target symptoms, and there are no drugs or other treatments that effectively delay the relentless loss of striatal volume in affected patients. Extending MSC-based therapies to neurodegenerative diseases, in particular those for which there are currently no effective treatments, such as HD (Fig. 2), could have a high potential benefit to risk ratio.

Acknowledgments Our work on MSC therapy for Huntington's disease and other neurodegenerative disorders is funded by the California Institute for Regenerative Medicine (CIRM) grants no. TR1-01257 (Nolta) and DR2-05415 (Wheelock), UC Davis CTSC pilot project 2P51RR000169-49, CIRM Training Grant to UC Davis, CIRM Bridges to Stem Cell Training Grant to California State University, Sacramento, NIH NHLBI 1RO1 HL073256-01 (Nolta), NIH Director's transformative award 1R01GM099688 (Nolta), 5P30AG010129-19 (DeCarli PI: Olson-Pilot project PI), and philanthropic donors from the HD community including the Roberson family and TeamKJ. We thank the HD patients and their families who provide daily inspiration to our group.

Author contributions Scott D. Olson, Kari Pollock, Amal Kambal, Whitney Cary, Gaela-Marie Mitchell, Jeremy Tempkin, Hyun Sook Kim and Jeannine McGee performed conception and design, collection and/or assembly of data, data analysis and interpretation, final approval of manuscript. Gerhard Bauer performed manuscript writing and final approval of manuscript. Geralyn Annett was responsible for conception and design, manuscript writing, and final approval of manuscript. Gary Dunbar and Jan A. Nolta carried out conception and design, assembly of data, data analysis and interpretation, manuscript writing, and final approval of manuscript.

Open Access This article is distributed under the terms of the Creative Commons Attribution Noncommercial License which permits any noncommercial use, distribution, and reproduction in any medium, provided the original author(s) and source are credited.

\section{References}

1. Joyce N, Annett G, Wirthlin L, Olson S, Bauer G, Nolta JA (2010) Mesenchymal stem cells for the treatment of neurodegenerative disease. Regenerative med 5:933-946
2. Meyerrose T, Olson S, Pontow S, Kalomoiris S, Jung Y, Annett G, Bauer G, Nolta JA (2010) Mesenchymal stem cells for the sustained in vivo delivery of bioactive factors. Adv drug deliv rev 62:1167-1174

3. Le Blanc K (2006) Mesenchymal stromal cells: tissue repair and immune modulation. Cytotherapy 8:559-561

4. Hare JM, Traverse JH, Henry TD, Dib N, Strumpf RK, Schulman SP, Gerstenblith G, DeMaria AN, Denktas AE, Gammon RS, Hermiller JB Jr, Reisman MA, Schaer GL, Sherman W (2009) A randomized, double-blind, placebocontrolled, dose-escalation study of intravenous adult human mesenchymal stem cells (prochymal) after acute myocardial infarction. J Am Coll Cardiol 54:2277-2286

5. Newman RE, Yoo D, LeRoux MA, Danilkovitch-Miagkova A (2009) Treatment of inflammatory diseases with mesenchymal stem cells. Inflamm allergy drug targets 8:110-123

6. Laflamme MA, Murry CE (2005) Regenerating the heart. Nat Biotechnol 23:845-856

7. Chen J, Li Y, Katakowski M, Chen X, Wang L, Lu D, Lu M, Gautam SC, Chopp M (2003) Intravenous bone marrow stromal cell therapy reduces apoptosis and promotes endogenous cell proliferation after stroke in female rat. J Neurosci Res 73:778-786

8. Li Y, Chen J, Zhang CL, Wang L, Lu D, Katakowski M, Gao Q, Shen LH, Zhang J, Lu M, Chopp M (2005) Gliosis and brain remodeling after treatment of stroke in rats with marrow stromal cells. Glia 49:407-417

9. Murphy JM, Fink DJ, Hunziker EB, Barry FP (2003) Stem cell therapy in a caprine model of osteoarthritis. Arthritis Rheum 48:3464-3474

10. Rosova I, Dao M, Capoccia B, Link D, Nolta JA (2008) Hypoxic preconditioning results in increased motility and improved therapeutic potential of human mesenchymal stem cells. Stem Cells 26:2173-2182

11. Kinnaird T, Stabile E, Burnett MS, Lee CW, Barr S, Fuchs S, Epstein SE (2004) Marrow-derived stromal cells express genes encoding a broad spectrum of arteriogenic cytokines and promote in vitro and in vivo arteriogenesis through paracrine mechanisms. Circ Res 94:678-685

12. Gnecchi M, He H, Noiseux N, Liang OD, Zhang L, Morello F, Mu H, Melo LG, Pratt RE, Ingwall JS, Dzau VJ (2006) Evidence supporting paracrine hypothesis for Akt-modified mesenchymal stem cell-mediated cardiac protection and functional improvement. FASEB J 20:661-669

13. Capoccia BJ, Robson DL, Levac KD, Maxwell DJ, Hohm SA, Neelamkavil MJ, Bell GI, Xenocostas A, Link DC, PiwnicaWorms D, Nolta JA, Hess DA (2009) Revascularization of ischemic limbs after transplantation of human bone marrow cells with high aldehyde dehydrogenase activity. Blood 113:5340-5351

14. Rosova I, Dao M, Capoccia B, Link D, Nolta JA (2008) Hypoxic preconditioning results in increased motility and improved therapeutic potential of human mesenchymal stem cells. Stem Cells 26:2173-2182

15. Wu GD, Nolta JA, Jin YS, Barr ML, Yu H, Starnes VA, Cramer DV (2003) Migration of mesenchymal stem cells to heart allografts during chronic rejection. Transplantation 75:679-685

16. Meyerrose T, De Ugarte D, Hofling A, Herrbrich PE, Cordonnier TD, Shultz LD, Eagon JC, Wirthlin L, Sands MS, Hedrick MA, Nolta JA (2007) In vivo distribution of human adipose-derived mesenchymal stem cells in novel xenotransplantation models. Stem Cells 25:220-227

17. Meyerrose TE, Roberts M, Ohlemiller KK, Vogler CA, Wirthlin L, Nolta JA, Sands MS (2008) Lentiviral-transduced human mesenchymal stem cells persistently express therapeutic levels of enzyme in a xenotransplantation model of human disease. Stem Cells 26:1713-1722 
18. Bauer G, Dao MA, Case SS, Meyerrose T, Wirthlin L, Zhou P, Wang X, Herrbrich P, Arevalo J, Csik S, Skelton DC, Walker J, Pepper K, Kohn DB, Nolta JA (2008) In vivo biosafety model to assess the risk of adverse events from retroviral and lentiviral vectors. Mol Ther 16:1308-1315

19. Dao MA, Pepper KA, Nolta JA (1997) Long-term cytokine production from engineered primary human stromal cells influences human hematopoiesis in an in vivo xenograft model. Stem Cells 15:443-454

20. Nolta J (2006) Genetic Engineering of Mesenchymal Stem Cells: Kluwer.

21. Danielyan L, Schafer R, von Ameln-Mayerhofer A, Buadze M, Geisler J, Klopfer T, Burkhardt U, Proksch B, Verleysdonk S, Ayturan M, Buniatian GH, Gleiter CH, Frey WH 2nd (2009) Intranasal delivery of cells to the brain. Eur $\mathrm{j}$ cell biol 88:315-324

22. Rossignol J, Boyer C, Thinard R, Remy S, Dugast AS, Dubayle D, Dey ND, Boeffard F, Delecrin J, Heymann D, Vanhove B, Anegon I, Naveilhan P, Dunbar GL, Lescaudron L (2009) Mesenchymal stem cells induce a weak immune response in the rat striatum after allo or xenotransplantation. J Cell Mol Med $13: 2547-2558$

23. Crigler L, Robey RC, Asawachaicharn A, Gaupp D, Phinney DG (2006) Human mesenchymal stem cell subpopulations express a variety of neuro-regulatory molecules and promote neuronal cell survival and neuritogenesis. Exp Neurol 198:54-64

24. Munoz JR, Stoutenger BR, Robinson AP, Spees JL, Prockop DJ (2005) Human stem/progenitor cells from bone marrow promote neurogenesis of endogenous neural stem cells in the hippocampus of mice. Proc Natl Acad Sci U S A 102:1817118176

25. Kassis I, Grigoriadis N, Gowda-Kurkalli B, Mizrachi-Kol R, Ben-Hur T, Slavin S, Abramsky O, Karussis D (2008) Neuroprotection and immunomodulation with mesenchymal stem cells in chronic experimental autoimmune encephalomyelitis. Arch Neurol 65:753-761

26. Busch SA, Hamilton JA, Horn KP, Cuascut FX, Cutrone R, Lehman N, Deans RJ, Ting AE, Mays RW, Silver J (2011) Multipotent adult progenitor cells prevent macrophage-mediated axonal dieback and promote regrowth after spinal cord injury. J Neurosci 31:944-953

27. Vercelli A, Mereuta OM, Garbossa D, Muraca G, Mareschi K, Rustichelli D, Ferrero I, Mazzini L, Madon E, Fagioli F (2008) Human mesenchymal stem cell transplantation extends survival, improves motor performance and decreases neuroinflammation in mouse model of amyotrophic lateral sclerosis. Neurobiol Dis 31:395-405

28. Morita E, Watanabe Y, Ishimoto M, Nakano T, Kitayama M, Yasui K, Fukada Y, Doi K, Karunaratne A, Murrell WG, Sutharsan R, Mackay-Sim A, Hata Y, Nakashima K (2008) A novel cell transplantation protocol and its application to an ALS mouse model. Exp Neurol 213:431-438

29. Josse C, Schoemans R, Niessen NA, Delgaudine M, Hellin AC, Herens C, Delvenne P, Bours V (2010) Systematic chromosomal aberrations found in murine bone marrow-derived mesenchymal stem cells. Stem cells dev 19:1167-1173

30. Rosland GV, Svendsen A, Torsvik A, Sobala E, McCormack E, Immervoll H, Mysliwietz J, Tonn JC, Goldbrunner R, Lonning PE, Bjerkvig R, Schichor C (2009) Long-term cultures of bone marrow-derived human mesenchymal stem cells frequently undergo spontaneous malignant transformation. Cancer Res 69:5331-5339

31. Torsvik A, Rosland GV, Svendsen A, Molven A, Immervoll H, McCormack E, Lonning PE, Primon M, Sobala E, Tonn JC, Goldbrunner R, Schichor C, Mysliwietz J, Lah TT, Motaln H, Knappskog S, Bjerkvig R (2010) Spontaneous malignant transformation of human mesenchymal stem cells reflects cross-contamination: putting the research field on track-letter. Cancer Res 70:6393-6396

32. Choi YH, Kurtz A, Stamm C (2011) Mesenchymal stem cells for cardiac cell therapy. Hum Gene Ther 22:3-17

33. Dryden GW (2009) Overview of stem cell therapy for Crohn's disease. Expert Opin Biol Ther 9:841-847

34. Kebriaei P, Robinson S (2011) Treatment of graft-versus-hostdisease with mesenchymal stromal cells. Cytotherapy 13:262-268

35. Matthay MA, Thompson BT, Read EJ, McKenna DH Jr, Liu KD, Calfee CS, Lee JW (2010) Therapeutic potential of mesenchymal stem cells for severe acute lung injury. Chest 138:965-972

36. Satija NK, Singh VK, Verma YK, Gupta P, Sharma S, Afrin F, Sharma M, Sharma P, Tripathi RP, Gurudutta GU (2009) Mesenchymal stem cell-based therapy: a new paradigm in regenerative medicine. J Cell Mol Med 13:4385-4402

37. Spitkovsky D, Hescheler J (2008) Adult mesenchymal stromal stem cells for therapeutic applications. Minim Invasive Ther Allied Technol 17:79-90

38. Wright KT, Masri WE, Osman A, Chowdhury J, Johnson WE (2011) Concise review: bone marrow for the treatment of spinal cord injury: mechanisms and clinical applications. Stem Cells 29:169-178

39. Kidd S, Spaeth E, Dembinski JL, Dietrich M, Watson K, Klopp A, Battula VL, Weil M, Andreeff M, Marini FC (2009) Direct evidence of mesenchymal stem cell tropism for tumor and wounding microenvironments using in vivo bioluminescent imaging. Stem Cells 27:2614-2623

40. Kidd S, Spaeth E, Klopp A, Andreeff M, Hall B, Marini FC (2008) The (in) auspicious role of mesenchymal stromal cells in cancer: be it friend or foe. Cytotherapy 10:657-667

41. Biglan KM, Ross CA, Langbehn DR, Aylward EH, Stout JC, Queller S, Carlozzi NE, Duff K, Beglinger LJ, Paulsen JS (2009) Motor abnormalities in premanifest persons with Huntington's disease: The PREDICT-HD study. Mov Disord 24:1763-1772

42. Paulsen JS, Magnotta VA, Mikos AE, Paulson HL, Penziner E, Andreasen NC, Nopoulos PC (2006) Brain structure in preclinical Huntington's disease. Biol Psychiatry 59:57-63

43. Kim HJ, McMillan E, Han F, Svendsen CN (2009) Regionally specified human neural progenitor cells derived from the mesencephalon and forebrain undergo increased neurogenesis following overexpression of ASCL1. Stem Cells 27:390-398

44. Sharp J, Keirstead HS (2009) Stem cell-based cell replacement strategies for the central nervous system. Neurosci Lett 456:107-111

45. Hardy SA, Maltman DJ, Przyborski SA (2008) Mesenchymal stem cells as mediators of neural differentiation. Curr stem cell res ther 3:43-52

46. Montzka K, Lassonczyk N, Tschoke B, Neuss S, Fuhrmann T, Franzen R, Smeets R, Brook GA, Woltje M (2009) Neural differentiation potential of human bone marrow-derived mesenchymal stromal cells: misleading marker gene expression. BMC Neurosci 10:16

47. Gahan PB, Stroun M (2010) The virtosome-a novel cytosolic informative entity and intercellular messenger. Cell Biochem Funct 28:529-538

48. Gerdes HH, Carvalho RN (2008) Intercellular transfer mediated by tunneling nanotubes. Curr Opin Cell Biol 20:470-475

49. Simons M, Raposo G (2009) Exosomes-vesicular carriers for intercellular communication. Curr Opin Cell Biol 21: 575-581

50. Bruno S, Grange C, Deregibus MC, Calogero RA, Saviozzi S, Collino F, Morando L, Busca A, Falda M, Bussolati B, Tetta C, 
Camussi G (2009) Mesenchymal stem cell-derived microvesicles protect against acute tubular injury. J Am Soc Nephrol 20:1053-1067

51. Quesenberry PJ, Aliotta JM (2008) The paradoxical dynamism of marrow stem cells: considerations of stem cells, niches, and microvesicles. Stem Cell Rev 4:137-147

52. Skinner AM, O’Neill SL, Kurre P (2009) Cellular microvesicle pathways can be targeted to transfer genetic information between non-immune cells. PLoS One 4:e6219

53. Taylor DD, Gercel-Taylor C (2011) Exosomes/microvesicles: mediators of cancer-associated immunosuppressive microenvironments. Seminars Immunopathol 33:441-454

54. Ratajczak J, Miekus K, Kucia M, Zhang J, Reca R, Dvorak P, Ratajczak MZ (2006) Embryonic stem cell-derived microvesicles reprogram hematopoietic progenitors: evidence for horizontal transfer of mRNA and protein delivery. Leukemia 20:847-856

55. Olson SD, Kambal A, Pollock K, Mitchell GM, Stewart H, Kalomoiris S, Cary W, Nacey C, Pepper K, Nolta JA (2011) Examination of Mesenchymal stem cell-mediated RNAi transfer to Huntington's disease affected neuronal cells for reduction of huntingtin. Molecular Neurology (in press)

56. Spees JL, Olson SD, Whitney MJ, Prockop DJ (2006) Mitochondrial transfer between cells can rescue aerobic respiration. Proc Natl Acad Sci U S A 103:1283-1288

57. Wilkins A, Kemp K, Ginty M, Hares K, Mallam E, Scolding N (2011) Human bone marrow-derived mesenchymal stem cells secrete brain-derived neurotrophic factor which promotes neuronal survival in vitro. Stem Cell Res

58. Aizman I, Tate CC, McGrogan M, Case CC (2009) Extracellular matrix produced by bone marrow stromal cells and by their derivative, SB623 cells, supports neural cell growth. J Neurosci Res 87:3198-3206

59. Croft AP, Przyborski SA (2009) Mesenchymal stem cells expressing neural antigens instruct a neurogenic cell fate on neural stem cells. Exp Neurol 216:329-341

60. Delcroix GJ, Schiller PC, Benoit JP, Montero-Menei CN (2010) Adult cell therapy for brain neuronal damages and the role of tissue engineering. Biomaterials 31:2105-2120

61. Zuccato C, Ciammola A, Rigamonti D, Leavitt BR, Goffredo D, Conti L, MacDonald ME, Friedlander RM, Silani V, Hayden MR, Timmusk T, Sipione S, Cattaneo E (2001) Loss of huntingtin-mediated BDNF gene transcription in Huntington's disease. Science 293:493-498

62. Zuccato C, Valenza M, Cattaneo E (2010) Molecular mechanisms and potential therapeutical targets in Huntington's disease. Physiol Rev 90:905-981

63. Croll SD, Suri C, Compton DL, Simmons MV, Yancopoulos GD, Lindsay RM, Wiegand SJ, Rudge JS, Scharfman HE (1999) Brain-derived neurotrophic factor transgenic mice exhibit passive avoidance deficits, increased seizure severity and in vitro hyperexcitability in the hippocampus and entorhinal cortex. Neuroscience 93:1491-1506

64. Boudreau RL, McBride JL, Martins I, Shen S, Xing Y, Carter BJ, Davidson BL (2009) Nonallele-specific silencing of mutant and wild-type huntingtin demonstrates therapeutic efficacy in Huntington's disease mice. Mol Ther 17:1053-1063

65. Harper SQ, Staber PD, He X, Eliason SL, Martins IH, Mao Q, Yang L, Kotin RM, Paulson HL, Davidson BL (2005) RNA interference improves motor and neuropathological abnormalities in a Huntington's disease mouse model. Proc Natl Acad Sci U S A 102:5820-5825

66. DiFiglia M, Sena-Esteves M, Chase K, Sapp E, Pfister E, Sass M, Yoder J, Reeves P, Pandey RK, Rajeev KG, Manoharan M, Sah DW, Zamore PD, Aronin N (2007) Therapeutic silencing of mutant huntingtin with siRNA attenuates striatal and cortical neuropathology and behavioral deficits. Proc Natl Acad Sci U S A 104:17204-17209

67. Wang YL, Liu W, Wada E, Murata M, Wada K, Kanazawa I (2005) Clinico-pathological rescue of a model mouse of Huntington's disease by siRNA. Neurosci Res 53:241-249

68. Lombardi MS, Jaspers L, Spronkmans C, Gellera C, Taroni F, Di Maria E, Donato SD, Kaemmerer WF (2009) A majority of Huntington's disease patients may be treatable by individualized allele-specific RNA interference. Exp Neurol 217:312-319

69. Pfister EL, Kennington L, Straubhaar J, Wagh S, Liu W, DiFiglia M, Landwehrmeyer B, Vonsattel JP, Zamore PD, Aronin N (2009) Five siRNAs targeting three SNPs may provide therapy for three-quarters of Huntington's disease patients. Curr Biol 19:774-778

70. Zhang Y, Engelman J, Friedlander RM (2009) Allele-specific silencing of mutant Huntington's disease gene. J Neurochem 108:82-90

71. Lescaudron L, Unni D, Dunbar GL (2003) Autologous adult bone marrow stem cell transplantation in an animal model of huntington's disease: behavioral and morphological outcomes. Int J Neurosci 113:945-956

72. Bantubungi K, Blum D, Cuvelier L, Wislet-Gendebien S, Rogister B, Brouillet E, Schiffmann SN (2008) Stem cell factor and mesenchymal and neural stem cell transplantation in a rat model of Huntington's disease. Mol Cell Neurosci 37:454-470

73. Amin EM, Reza BA, Morteza BR, Maryam MM, Ali M, Zeinab N (2008) Microanatomical evidences for potential of mesenchymal stem cells in amelioration of striatal degeneration. Neurol Res 30:1086-1090

74. Watts C, McNamara IR, Dunnett SB (2000) Volume and differentiation of striatal grafts in rats: relationship to the number of cells implanted. Cell transplant 9:65-72

75. Dey ND, Bombard MC, Roland BP, Davidson S, Lu M, Rossignol J, Sandstrom MI, Skeel RL, Lescaudron L, Dunbar GL (2010) Genetically engineered mesenchymal stem cells reduce behavioral deficits in the YAC 128 mouse model of Huntington's disease. Behav brain res 214:193-200

76. Edalatmanesh MA, Matin MM, Neshati Z, Bahrami AR, Kheirabadi M (2010) Systemic transplantation of mesenchymal stem cells can reduce cognitive and motor deficits in rats with unilateral lesions of the neostriatum. Neurol Res 32:166-172

77. Im W, Lee ST, Park JE, Oh HJ, Shim J, Lim J, Chu K, Kim M (2010) Transplantation of patient-derived adipose stem cells in YAC128 Huntington's disease transgenic mice. PLoS Curr 2

78. Jiang Y, Lv H, Huang S, Tan H, Zhang Y, Li H (2011) Bone marrow mesenchymal stem cells can improve the motor function of a Huntington's disease rat model. Neurol Res 33:331-337

79. Lee ST, Chu K, Jung KH, Im WS, Park JE, Lim HC, Won CH, Shin SH, Lee SK, Kim M, Roh JK (2009) Slowed progression in models of Huntington disease by adipose stem cell transplantation. Ann Neurol 66:671-681

80. Lin YT, Chern Y, Shen CK, Wen HL, Chang YC, Li H, Cheng TH, Hsieh-Li HM (2011) Human mesenchymal stem cells prolong survival and ameliorate motor deficit through trophic support in Huntington's disease mouse models. PLoS One 6: e22924

81. Rossignol J, Boyer C, Leveque $\mathrm{X}$, Fink $\mathrm{KD}$, Thinard $\mathrm{R}$, Blanchard F, Dunbar GL, Lescaudron L (2011) Mesenchymal stem cell transplantation and DMEM administration in a $3 \mathrm{NP}$ rat model of Huntington's disease: morphological and behavioral outcomes. Behav brain res 217:369-378

82. Sadan O, Shemesh N, Barzilay R, Bahat-Stromza M, Melamed E, Cohen Y, Offen D (2008) Migration of neurotrophic factorssecreting mesenchymal stem cells toward a quinolinic acid lesion as viewed by magnetic resonance imaging. Stem Cells 26:2542-2551 
83. Delcroix GJ, Jacquart M, Lemaire L, Sindji L, Franconi F, Le Jeune JJ, Montero-Menei CN (2009) Mesenchymal and neural stem cells labeled with HEDP-coated SPIO nanoparticles: in vitro characterization and migration potential in rat brain. Brain res 1255:18-31

84. Sadan O, Shemesh N, Cohen Y, Melamed E, Offen D (2009) Adult neurotrophic factor-secreting stem cells: a potential novel therapy for neurodegenerative diseases. Isr Med Assoc J 11:201-204

85. Bachoud-Levi AC, Gaura V, Brugieres P, Lefaucheur JP, Boisse MF, Maison P, Baudic S, Ribeiro MJ, Bourdet C, Remy P, Cesaro P, Hantraye P, Peschanski M (2006) Effect of fetal neural transplants in patients with Huntington's disease 6 years after surgery: a long-term follow-up study. Lancet Neurol 5:303-309

86. Gaura V, Bachoud-Levi AC, Ribeiro MJ, Nguyen JP, Frouin V, Baudic S, Brugieres P, Mangin JF, Boisse MF, Palfi S, Cesaro P, Samson Y, Hantraye P, Peschanski M, Remy P (2004) Striatal neural grafting improves cortical metabolism in Huntington's disease patients. Brain 127:65-72

87. Altar CA, Cai N, Bliven T, Juhasz M, Conner JM, Acheson AL, Lindsay RM, Wiegand SJ (1997) Anterograde transport of brainderived neurotrophic factor and its role in the brain. Nature 389:856-860

88. Baquet ZC, Gorski JA, Jones KR (2004) Early striatal dendrite deficits followed by neuron loss with advanced age in the absence of anterograde cortical brain-derived neurotrophic factor. J Neurosci 24:4250-4258

89. Zuccato C, Cattaneo E (2009) Brain-derived neurotrophic factor in neurodegenerative diseases. Nat rev 5:311-322

90. Arregui L, Benitez JA, Razgado LF, Vergara P, Segovia J (2011) Adenoviral astrocyte-specific expression of BDNF in the striata of mice transgenic for Huntington's disease delays the onset of the motor phenotype. Cell Mol Neurobiol 31:1229-1243

91. Alberch J, Perez-Navarro E, Canals JM (2004) Neurotrophic factors in Huntington's disease. Prog brain res 146:195-229

92. Zuccato C, Cattaneo E (2007) Role of brain-derived neurotrophic factor in Huntington's disease. Prog Neurobiol 81:294-330

93. Dey ND, Bombard MC, Roland BP, Davidson S, Lu M, Rossignol J, Sandstrom MI, Skeel RL, Lescaudron L, Dunbar GL (2010) Genetically-engineered mesenchymal stem cells reduce behavioral deficits in the YAC 128 mouse model of Huntington's disease. Behav Brain Res 214:193-200

94. Meyerrose T, Rosova I, Dao M, Herrbrich P, Bauer G, Nolta J (2006) Establishment and transduction of primary human stromal/mesenchymal stem cell monolayers, Vol. Chapter 2. Kluwer Academic, Dordrecht

95. Nolta JA, Dao MA, Wells S, Smogorzewska EM, Kohn DB (1996) Transduction of pluripotent human hematopoietic stem cells demonstrated by clonal analysis after engraftment in immune-deficient mice. Proc Natl Acad Sci U S A 93:2414-2419

96. Nolta JA, Kohn DB (1990) Comparison of the effects of growth factors on retroviral vector-mediated gene transfer and the proliferative status of human hematopoietic progenitor cells. Hum Gene Ther 1:257-268

97. Tsark E, Dao M, Wang X, Weinberg K, Nolta J (2001) IL-7 enhances the responsiveness of human T cells that develop in the bone marrow of athymic mice. J Immunol 166:170-181

98. Wang X, Ge S, McNamara G, Hao QL, Crooks GM, Nolta JA (2003) Albumin expressing hepatocyte-like cells develop in the livers of immune-deficient mice transmitted with highly purified human hematopoietic stem cells. Blood 101(10):4201-4208
99. Nolta JA, Hanley MB, Kohn DB (1994) Sustained human hematopoiesis in immunodeficient mice by cotransplantation of marrow stroma expressing human interleukin-3: analysis of gene transduction of long-lived progenitors. Blood 83:3041-3051

100. Mazzini L, Fagioli F, Boccaletti R, Mareschi K, Oliveri G, Olivieri C, Pastore I, Marasso R, Madon E (2003) Stem cell therapy in amyotrophic lateral sclerosis: a methodological approach in humans. Amyotroph Lateral Scler Other Motor Neuron Disord 4:158-161

101. Mazzini L, Ferrero I, Luparello V, Rustichelli D, Gunetti M, Mareschi K, Testa L, Stecco A, Tarletti R, Miglioretti M, Fava E, Nasuelli N, Cisari C, Massara M, Vercelli R, Oggioni GD, Carriero A, Cantello R, Monaco F, Fagioli F (2010) Mesenchymal stem cell transplantation in amyotrophic lateral sclerosis: A Phase I clinical trial. Experimental Neurol 223:229-237

102. Karussis D, Kassis I, Kurkalli BG, Slavin S (2008) Immunomodulation and neuroprotection with mesenchymal bone marrow stem cells (MSCs): a proposed treatment for multiple sclerosis and other neuroimmunological/neurodegenerative diseases. J Neurol Sci 265:131-135

103. Karussis D, Karageorgiou C, Vaknin-Dembinsky A, GowdaKurkalli B, Gomori JM, Kassis I, Bulte JW, Petrou P, Ben-Hur T, Abramsky O, Slavin S (2010) Safety and immunological effects of mesenchymal stem cell transplantation in patients with multiple sclerosis and amyotrophic lateral sclerosis. Arch Neurol 67:1187-1194

104. Karussis D (2010) “multiple sclerosis AND stem cell”. ClinicalTrialsgov A service of the US National Institutes of Health

105. Bonab MM, Yazdanbakhsh S, Lofti J (2010) Does mesenchymal stem cell therapy help multiple sclerosis patients? Report of a pilot study. Iran J Immunol 4:50-57

106. Liang J, Zhang H, Hua B, Wang H, Wang J, Han Z, Sun L (2009) Allogeneic mesenchymal stem cells transplantation in treatment of multiple sclerosis. Mult Scler 15:644-646

107. Saccardi R, Kozak T, Bocelli-Tyndall C, Fassas A, Kazis A, Havrdova E, Carreras E, Saiz A, Lowenberg B, te Boekhorst PA, Gualandio F, Openshaw H, Longo G, Pagliai F, Massacesi L, Deconink E, Ouyang J, Nagore FJ, Besalduch J, Lisukov IA, Bonini A, Merelli E, Slavino S, Gratwohl A, Passweg J, Tyndall A, Steck AJ, Andolina M, Capobianco M, Martin JL, Lugaresi A, Meucci G, Saez RA, Clark RE, Fernandez MN, Fouillard L, Herstenstein B, Koza V, Cocco E, Baurmann H, Mancardi GL (2006) Autologous stem cell transplantation for progressive multiple sclerosis: update of the European Group for Blood and Marrow Transplantation autoimmune diseases working party database. Mult Scler 12:814-823

108. Zhang ZX, Guan LX, Zhang K, Zhang Q, Dai LJ (2008) A combined procedure to deliver autologous mesenchymal stromal cells to patients with traumatic brain injury. Cytotherapy 10:134-139

109. Venkataramana NK, Kumar SK, Balaraju S, Radhakrishnan RC, Bansal A, Dixit A, Rao DK, Das M, Jan M, Gupta PK, Totey SM (2010) Open-labeled study of unilateral autologous bonemarrow-derived mesenchymal stem cell transplantation in Parkinson's disease. Transl Res 155:62-70

110. Mays RW, van't Hof W, Ting AE, Perry R, Deans R (2007) Development of adult pluripotent stem cell therapies for ischemic injury and disease. Expert Opin Biol Ther 7:173-184

111. Ting AE, Mays RW, Frey MR, Hof WV, Medicetty S, Deans R (2008) Therapeutic pathways of adult stem cell repair. Crit rev oncol/hematol 65:81-93 